\title{
SPORTS TOURISM DEVELOPMENT STRATEGY FOR PHYSICAL DISABILITIES IN BENGKULU CITY
}

\author{
Yahya Eko Nopiyanto ${ }^{1 *}$, Ari Sutisyana ${ }^{2}$, M Fadli Dongoran ${ }^{3}$ \\ ${ }^{1,2}$ Physical Education, University of Bengkulu, Bengkulu, Indonesia \\ ${ }^{3}$ Physical Education, University of Musamus, Papua, Indonesia
}

\section{Article Info}

Article History :

Received : October 2021

Revised : November 2021

Accepted :December 2021

Available online : December 2021

\section{Keywords:}

Disability, Strategy, Sports tourism,

\begin{abstract}
The purpose of this study was to formulate a strategy for developing sports tourism for people with physical disabilities in Bengkulu City. The method used in this research was descriptive qualitative. The data analysis technique used SWOT analysis. The results of data analysis show that the results of IFAS and EFAS were used to determine the position of the quadrant. Strengths and weaknesses produce the $\mathrm{X}$-axis, namely $\mathrm{X}=1.93-1.71=0.21$, and the $\mathrm{Y}$-axis represents opportunities - threats, namely $\mathrm{Y}=1.04-2.12=-1.08$ to produce quadrant II or strategy diversification. The strategy applied in this condition is the Strength-Threat, namely: 1) formulating a clear vision and mission to make the Pantai Panjang Tourism Location a friendly sports tourism location for physical disabilities, 2) equipping accessible facilities and infrastructure for physical disabilities at the Semarak Stadium and Youth Sports Center and increase promotion to the public about the achievements of athletes with physical disabilities, 3) involving the Youth and Sports Office, the Indonesian National Sports Committee, academics, private parties and sports clubs in fostering sports achievements, 4) involving the private sector for the development of facilities and infrastructure for physical disabilities, 5) involving the private sector to develop sports clubs for people with physical disabilities.
\end{abstract}

\footnotetext{
Corresponding address

: Hibrida XI A, Bengkulu, Indonesia

: yahyaekonopiyanto@unib.ac.id

ISSN 2685-6514 (Online)

ISSN 2477-331X (Print)
} 


\section{INTRODUCTION}

Tourism services are public services that are the right of every citizen and these services can be felt by all people, including tourists who fall into the category of physical disabilities (Hua, Ibrahim, \& Chiu, 2013; Darcy, \& Buhalis, 2010). Based on Law Number 8 of 2016 concerning Persons with Disabilities, one of them is regarding the rights of persons with disabilities to culture and tourism. However, at a practical level in the field, it is known that there are still many tourist attractions that do not provide suitable facilities for all people and the provision of public service facilities for physical disabilities is still far from expectations (Chikuta, du Plessis, \& Saayman, 2019).

Article 9 of Law no. 9 of 2011 guarantees that persons with disabilities or those with physical, mental, intellectual, or sensory disabilities have the right to obtain the fulfillment of accessibility rights. This right is very important to guarantee the independence and participation of persons with disabilities in all aspects of life (Arawindha, \& Fitrianita, 2018). One of the many needs for people with disabilities is the need for a tourism model that is friendly to people with physical disabilities.

Persons with physical disabilities are a term to refer to someone who has physical abnormalities consisting of visually impaired, physically disabled, deaf, and speech impaired (Kaganek et al, 2017). The concept of friendly tourism for people with physical disabilities is tourism that can meet facilities and infrastructure that are easily accessible to people with disabilities. This is also in line with Article 30 of the United Nations Convention on The Rights of Persons with Disabilities (UNCRPD) and Law Number 19 of 2011 which states that in principle, everyone has the same right to access and enjoy tourism, including persons with disabilities. Article 5 of Law Number 4 of 1997 concerning Persons with Disabilities states that "Every person with disabilities has equal rights and opportunities in all aspects of life and livelihood." They have the right to be able to enjoy all kinds of tourism activities without any significant obstacles.

One type of tourism that can be done by persons with disabilities is sports tourism. Sports tourism is one type of tourism that makes sports activities the main attraction. Sports tourism includes all experiences gained from doing or practicing sports activities or just enjoying sports activities as spectacle or entertainment, which requires traveling from the place of residence and place of work (Mhanna, 2018).

Through Law Number 10 of 2009 concerning Tourism, the central government and local governments are required to provide sports tourism services that are easily accessible to persons with disabilities. However, the reality in Bengkulu City is that the accessibility of facilities and infrastructure that supports sports tourism is still very concerning. Many sports tourism places in Bengkulu City are not yet friendly to people with disabilities. Facilities and infrastructure that are not friendly to persons with disabilities make sports tourism places and activities inaccessible to persons with disabilities.

Bengkulu City has several places to become sports tourism destinations including the Pantai Panjang, Sports Center, Student Education, and Training Center (PPLP), Bengkulu Semarak Stadium, Youth Building, and Sports. Tourists who can enjoy sports tourism in these places are generally limited to those who have a normal physique, while people with physical disabilities encounter many obstacles in accessing existing facilities and infrastructure. Some examples include toilets, wheelchairs, and 
communication facilities, and stairs that are accessible for people with physical disabilities that have not been found in many places. The Bengkulu city government and managers of sports tourism attractions should work together to provide friendly facilities and infrastructure and a barrier-free sports tourism environment for people with physical disabilities. For this reason, it is necessary to develop the potential of sports tourism including facilities, human resources with character, competence, and collaboration, with policies and strategies that prioritize the implementation of tourism management (Siswanto, 2015).

\section{METHODS}

This research is qualitative research with descriptive thinking analysis on sports tourism development strategies for physical disabilities in the City of Bengkulu.

\section{Participants}

The research subject is someone who is chosen by the researcher as a source who can provide information and is selected purposely to obtain research information (Sugiyono, 2017). The subjects selected in this study as a source of information were the head of the Tourism Office, the head of the Youth and Sports Service, and the coach national paralympic Committee (NPC).

\section{Techniques and Instruments}

Techniques and instruments of data collection techniques in this study using observation, interviews, and documentation.

\section{Field observation}

Observations were made by direct observation of the research location, including the existing facilities and infrastructure at the research location.

\section{Interview}

Interviews were conducted with the Head of the Bengkulu City Tourism Office to find out the role of the tourism office in realizing tourism that is friendly to physical disabilities. Interview with the Bengkulu City Youth and Sports Office to find out the roles, strategies that have been implemented or are being designed by the head of the agency regarding sports that have high potential to be developed into tourism for physical disabilities. Interview with the coach of the National Paralympic Committee (NPC) of Bengkulu City to find out the ideal facilities and infrastructure for people with disabilities to do sports or travel.

\section{Documentation}

Documentation is carried out to find out sports tourism facilities and infrastructure for people with disabilities and sports tourism development policy documents.

\section{Data Analysis Techniques}

To find out the strategy for developing sports tourism for physical disabilities in Bengkulu City, it will be analyzed using a SWOT consisting of strengths, weaknesses, opportunities, threats that exist in sports tourism in Bengkulu City. The analysis technique used in this research is a qualitative analysis using data reduction, data presentation, and concluding.

\section{Data reduction}

Data reduction is a simplification that is carried out through selection, focusing, and the validity of raw data into meaningful information, making it easier to conclude.

\section{Presentation of data}

The presentation of data that is 
often used in qualitative data is in the form of narrative. Presentations of data in the form of a collection of information that is arranged systematically and easily understood.

\section{Drawing conclusions}

Drawing conclusions is the final stage in data analysis which is carried out to see if the results of data reduction still refer to the formulation of the problem in terms of the objectives to be achieved. The data that has been compiled is compared with one another to conclude answers to existing problems.

\section{RESULT}

Based on the results of the analysis of the strategic situation (internal and external environment) of sports tourism, several factors of strengths, weaknesses, opportunities, and threats are obtained as follows:

\section{Strengths}

1. Panjang Beach is one of the leading tourist attractions in Bengkulu City.

2. Availability of the Semarak Sawah Stadium and Pemuda Lebar Stadium as sports tourism locations.

3. Bengkulu City has outstanding athletes with physical disabilities.

4. Bengkulu City has outstanding trainers for people with physical disabilities.

5. The strategic location of the tourist attraction is not far from the city center.

\section{Weaknesses}

1. Sports facilities and infrastructure for physical disabilities are not optimal.

2. Management of sports tourism for physical disabilities has not run optimally.

3. Sports events for people with disabilities have not been running sustainably.
4. The empowerment of human resources is not yet optimal to manage sports tourism.

5. Weak socialization regarding sports tourism for physical disabilities.

\section{Opportunities}

1. Management of tourism objects through three elements, namely the government, the private sector, and the community.

2. Support of the Department of Tourism for the development of sports tourism.

3. Kadispora support for the development of sports tourism.

4. Support the National Paralympic Committee (NPC) for the development of sports tourism.

5. Availability of various kinds of social media applications making it easier for the socialization and marketing of sports tourism.

\section{Threats}

1. There is no clear vision and mission from the Bengkulu City government regarding the development of sports tourism for physical disabilities.

2. There is still a negative stigma from society towards physical disabilities.

3. There is no special allocation of funds from the Bengkulu city government for sports tourism for physical disabilities.

4. Lack of government support for facilities and infrastructure for physical disabilities.

5. Lack of appreciation from the government for people with physical disabilities who excel.

\section{Table 1. IFAS Matrix}

\begin{tabular}{llll}
\hline Internal Factor & & & \\
\hline Strength & $\begin{array}{l}\text { Weig Rating } \\
\text { ht }\end{array}$ & Score \\
\hline $\begin{array}{l}\text { 1. Pantai Panjang is } \\
\text { one of the leading } \\
\text { tourist attractions } \\
\text { in Bengkulu City. }\end{array}$ & 0.11 & 4 & 0.43 \\
\hline 2. Availability of & & & \\
Semarak Sawah & 0.07 & 3 & 0.21
\end{tabular}




\begin{tabular}{|c|c|c|c|}
\hline $\begin{array}{lr}\text { Stadium } & \text { and } \\
\text { Youth } & \text { Width } \\
\text { Gymnasium as } \\
\text { sports tourism } \\
\text { locations. }\end{array}$ & & & \\
\hline $\begin{array}{l}\text { 3. Bengkulu City has } \\
\text { outstanding } \\
\text { athletes with } \\
\text { physical } \\
\text { disabilities }\end{array}$ & 0.11 & 4 & 0.43 \\
\hline $\begin{array}{l}\text { 4. Bengkulu City has } \\
\text { outstanding } \\
\text { trainers for people } \\
\text { with physical } \\
\text { disabilities }\end{array}$ & 0.11 & 4 & 0.43 \\
\hline $\begin{array}{l}\text { 5. Strategically } \\
\text { located tourist } \\
\text { attractions not far } \\
\text { from the city } \\
\text { center. }\end{array}$ & 0.11 & 4 & 0.43 \\
\hline Subtotal & & & 1.93 \\
\hline \multicolumn{4}{|l|}{ Weaknesses } \\
\hline $\begin{array}{l}\text { 1. Sports facilities } \\
\text { and infrastructure } \\
\text { for physical } \\
\text { disabilities are not } \\
\text { optimal. }\end{array}$ & 0.11 & 4 & 0.43 \\
\hline $\begin{array}{l}\text { 2. Management of } \\
\text { sports tourism for } \\
\text { physical } \\
\text { disabilities has not } \\
\text { run optimally. }\end{array}$ & 0.11 & 3 & 0.32 \\
\hline $\begin{array}{l}\text { 3. Sports events for } \\
\text { people with } \\
\text { disabilities have } \\
\text { not been running } \\
\text { sustainably. }\end{array}$ & 0.11 & 4 & 0.43 \\
\hline $\begin{array}{l}\text { 4. Human resource } \\
\text { empowerment is } \\
\text { not optimal yet to } \\
\text { manage sports } \\
\text { tourism. }\end{array}$ & 0.11 & 3 & 0.32 \\
\hline $\begin{array}{l}\text { 5. Weak } \\
\text { socialization of } \\
\text { sports tourism for } \\
\text { physical } \\
\text { disabilities. }\end{array}$ & 0.07 & 3 & 0.21 \\
\hline Subtotal & & & 1.71 \\
\hline Total & 1 & & 3.64 \\
\hline
\end{tabular}

Table 2. EFAS Matrix

\begin{tabular}{lll}
\hline External Factors & & \\
\hline Opportunity & $\begin{array}{l}\text { Weig Rating } \\
\text { ht }\end{array}$ & Score \\
& & \\
\hline
\end{tabular}

\begin{tabular}{|c|c|c|c|c|}
\hline \multicolumn{2}{|r|}{$\begin{array}{l}\text { 1. Management of } \\
\text { tourism objects } \\
\text { through three } \\
\text { elements, namely } \\
\text { the government, } \\
\text { the private sector, } \\
\text { and the } \\
\text { community. }\end{array}$} & 0.08 & 4 & 0.32 \\
\hline & $\begin{array}{l}\text { Support of the } \\
\text { Department of } \\
\text { Tourism for the } \\
\text { development of } \\
\text { sports tourism. }\end{array}$ & 0.08 & 2 & 0.16 \\
\hline & $\begin{array}{l}\text { Support of the } \\
\text { Head of Youth } \\
\text { and Sports Affairs } \\
\text { for the } \\
\text { development of } \\
\text { sports tourism. }\end{array}$ & 0.08 & 2 & 0.16 \\
\hline 4. & $\begin{array}{l}\text { Support of the } \\
\text { National } \\
\text { Paralympic } \\
\text { Committee (NPC) } \\
\text { for tourism } \\
\text { development } \\
\text { sports. }\end{array}$ & 0.08 & 2 & 0.16 \\
\hline 5 . & $\begin{array}{l}\text { Availability of } \\
\text { various kinds of } \\
\text { social media } \\
\text { applications } \\
\text { making it easier } \\
\text { for the } \\
\text { socialization and } \\
\text { marketing of } \\
\text { sports tourism. }\end{array}$ & 0.12 & 2 & 0.24 \\
\hline & ibtotal & & & 1.04 \\
\hline & hreats & & & \\
\hline & $\begin{array}{l}\text { There is no clear } \\
\text { vision and mission } \\
\text { from the } \\
\text { Bengkulu City } \\
\text { government } \\
\text { regarding the } \\
\text { development of } \\
\text { sports tourism for } \\
\text { physical } \\
\text { disabilities. }\end{array}$ & 0.08 & 4 & 0.32 \\
\hline & $\begin{array}{l}\text { There is still a } \\
\text { negative stigma } \\
\text { from society } \\
\text { towards physical } \\
\text { disabilities. }\end{array}$ & 0.12 & 3 & 0.36 \\
\hline & $\begin{array}{l}\text { There has been no } \\
\text { special allocation } \\
\text { of funds from the } \\
\text { Bengkulu city } \\
\text { government for }\end{array}$ & 0.12 & 4 & 0.48 \\
\hline
\end{tabular}




\begin{tabular}{|c|c|c|c|c|}
\hline & \multicolumn{4}{|l|}{$\begin{array}{l}\text { sports tourism for } \\
\text { physical } \\
\text { disabilities. }\end{array}$} \\
\hline 4. & $\begin{array}{lr}\text { Lack } & \text { of } \\
\text { government } & \\
\text { support } & \text { for } \\
\text { facilities } & \text { and } \\
\text { infrastructure } & \text { for } \\
\text { physical } & \\
\text { disabilities. } & \\
\end{array}$ & 0.12 & 4 & 0.48 \\
\hline 5. & $\begin{array}{l}\text { Lack of } \\
\text { appreciation from } \\
\text { the government } \\
\text { for people with } \\
\text { physical } \\
\text { disabilities who } \\
\text { excel. }\end{array}$ & 0.12 & 4 & 0.48 \\
\hline Sul & total & & & 2.12 \\
\hline
\end{tabular}

The results of IFAS and EFAS are used to determine the position of the quadrant. Strengths and weaknesses produce the $\mathrm{X}$-axis, namely $\mathrm{X}=1.93$ $1.71=0.21$, and the $\mathrm{Y}$-axis is an opportunity - a threat, namely $\mathrm{Y}=1.04$ $2.12=-1.08$ to produce a quadrant as shown in Figure 1 following.

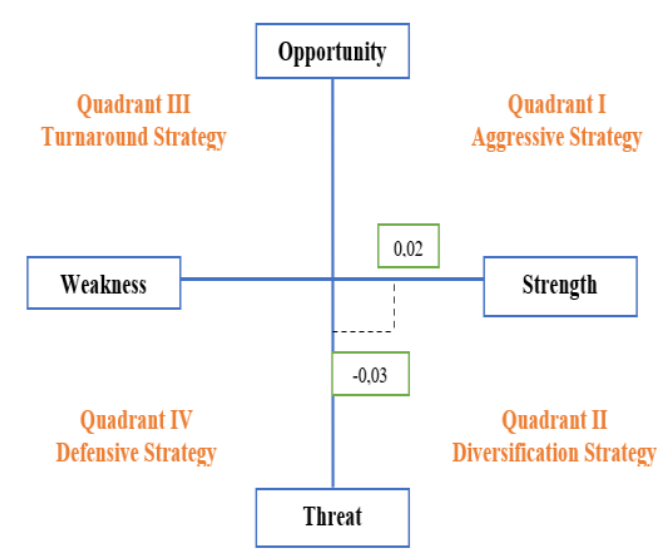

Figure 1. Result of SWOT

\section{DISCUSSION}

Based on the results of the IFAS analysis, it is known that Pantai Panjang is one of the leading tourist attractions in Bengkulu City. Bengkulu City has a very potential tourism potential to be developed. The other is Panjang Beach which is located on the west side of Bengkulu City which is a distance from the city center only about 2 kilometers. The strategic location and not far from the city center is a strength owned in addition to the beautiful panorama of nature and the sea so it needs to get serious attention from Bengkulu City to make Long Beach a tourist area that attracts tourists to come to Bengkulu City (Pratama \& Sakti, 2016).

In addition to the Pantai Panjang, the city of Bengkulu also has the availability of Semarak Stadium and Youth Width Gymnasium as sports tourism locations. Semarak Stadium is one of the biggest stadiums in the city of Bengkulu and it gives the strength to develop sports tourism. Currently, Indonesia only has 3 stadiums out of a minimum of 10 that have been certified to international standards, so Indonesia needs to increase the number of stadiums. The Bengkulu Provincial Government responded to this by planning the construction of an International Football Stadium which also simultaneously runs the "Sports Tourism of Bencoolen" program which is a tourism potential development program for Bengkulu Province through the sports sector (Oetomo, Teddy, \& Adiyanto, 2020).

In terms of internal factors, Bengkulu City also has outstanding athletes as a force to develop sports tourism. Outstanding athletes are one of the main components in the development of sports tourism (Osmanoglu \& Üzüm, 2018).

Another strength possessed by the city of Bengkulu to develop sports tourism is its strategic location such as long beach, wide rice field stadium, youth and sports building, sports center, and student education and training center. Strategic location is one source of strength in developing sports tourism (Sanusi, 2020). 
Although the city of Bengkulu has the strength to develop sports tourism for physical disabilities, there are also some weaknesses. The first weakness is sports facilities and infrastructure for physical disabilities are not optimal. Tourism development can be suppressed, one of which is by developing tourism destinations, wherein this tourism destination there are also public facilities, tourism facilities, and accessibility. By considering the principle of equality and upholding human rights, these three aspects must be utilized by everyone, without exception, including tourists with disabilities (Tan \& Hasibuan, 2019). The Bengkulu City Government has not developed sports tourism for disabled people. This is due to several factors including inadequate facilities and infrastructure, and unavailable funds. The statement was also expressed by respondents who were part of this research, namely Yulistri Heni, S.St as the Head of the Tourism Industry at the Tourism Office of Bengkulu City stating that:

"Facilities and infrastructure in Bengkulu City were not suitable for physical disabilities, especially in the Long Beach area. moreover, he said that there was no special budget from the tourism office to complete facilities and infrastructure for physical disabilities".

The statement was also expressed by respondents who were part of this research, namely Mr. Jaka Permana who had trained athletes with physical disabilities in athletic sports in Bengkulu City in an interview on July 10, 2021, stating that:

"The city of Bengkulu has not yet become a friendly place for physical disabilities to carry out sports tourism activities because there has not been a special place for people with physical disabilities. In addition, the provision of existing facilities and infrastructure at sports tourism locations has not provided convenience for people with physical disabilities."

The second weakness is the management of sports tourism for physical disabilities has not run optimally. An integrative approach to determine policies that allow coaching and development of national sports harmoniously, integrated, and long-term system-supported length funding with the principle of adequacy and sustainability is a thing that is very important in supporting sports development success (Rahardian at al., 2021). The statement was also expressed by respondents who were part of this research, namely Mr. Jang Jaya as Bengkulu City National Paralympics organizer in an interview on July 10, 2021, stating that:

"To be able to develop sports tourism in the city of Bengkulu, good cooperation is needed from various agencies such as the provincial government, city government, councils".

The third weakness is sports events for people with disabilities have not been running sustainably. The government and community support are very influential on sustainable sports events. However, Bengkulu City has not been able to develop sports tourism because there are no special funds for organizing sports tourism for physical disabilities. The statement was expressed by respondents who were part of this research, namely Rida Subhan, S.Ip, M.E as Head of Sports Cultivation Division of Youth and Sports Service in an interview c, 2021, stating that:

"The inhibiting factor for the development of sports tourism for physical disabilities is funds. The budget for sports is minimal due to budget cuts. 
The fourth weakness is human resource empowerment is not optimal yet to manage sports tourism. The existence of human resources plays an important role in tourism development (Setiawan, 2016). The role of human resources as workers can be in the form of human resources in government institutions, human resources who act as entrepreneurs who play a role in determining the satisfaction and quality of workers, experts and professionals who play a role in observing, controlling, and improving the quality of tourism and no less important is the community around the area also determines the comfort and satisfaction of tourists visiting the area. Bengkulu city has potential human resources to develop sports tourism but has not been developed optimally. These potential human resources include athletes with physical disabilities and outstanding coaches.

The fifth weakness is the weak socialization of sports tourism for physical disabilities. Strengths of sport as a tourist attraction include the length of time during which events take place, coverage of extensive publications through print and electronic media, sponsorship of various domestic and multinational companies, and business opportunities provided to residents during the event (Mapjabil et al., 2021). Unfortunately, the socialization of sports tourism for physical disabilities has not been carried out. The statement was expressed by Yulistri Heni, S.St as the Head of the Tourism Industry at the Tourism Office of Bengkulu City stating that:

"The socialization of sports tourism for physical disabilities has not been carried out because for people with physical disabilities it has not been included in the activities of the Bengkulu City Tourism Office"

Based on the results of the EFAS analysis that sports tourism in Bengkulu has five opportunities. First, management of tourism objects through three elements, namely the government, the private sector, and the community. Second, Support of the Department of Tourism for the development of sports tourism. Third, Support of the Head of Youth and Sports Affairs for the development of sports tourism. Fourth, Support of the National Paralympic Committee (NPC) for tourism development sports. Fifth, the availability of various kinds of social media applications making it easier for the socialization and marketing of sports tourism.

Based on the results of the EFAS analysis that sports tourism in Bengkulu has five threats. First, there is no clear vision and mission from the Bengkulu City government regarding the development of sports tourism for physical disabilities. The statement was expressed by Yulistri Heni, S.St as the Head of the Tourism Industry at the Tourism Office of Bengkulu City stating that:

"Sports tourism has not yet been included in the vision and mission of the Bengkulu City Tourism Office".

The second threat is still a negative stigma from society towards physical disabilities. The statement was expressed by Iyasman, S.Pd as a coach for disabilities athletes stating that:

"Many athletes with disabilities have national-level sports achievements such as National Paralympic Week but many people do not appreciate these achievements.

The third threat is There has been no special allocation of funds from the Bengkulu city government for sports tourism for physical disabilities. The statement was expressed by Rida Subhan, S.Ip, M.E as Head of Sports Cultivation Division of Youth and Sports Service in an interview on September 20, 2021, stating that: 
"Bengkulu city government in this case through the youth and sports office does not yet have special funds for the development of sports tourism for physical disabilities, so this is a serious threat in the development of sports tourism".

Accessible facilities and infrastructure are needed for physical disabilities (Danso, Atuahene, \& Agyekum, 2017). The fourth threat is the lack of government support for facilities and infrastructure for physical disabilities. The statement was expressed by Rida Subhan, S.Ip, M.E as Head of Sports Cultivation Division of Youth and Sports Service in an interview on September 20, 2021, stating that:

"It's not worth it if it's worth the funds and the budget is sufficient, especially since covid 19 has passed for 2 years when the year 2020 was originally there and we also proposed an addition because of this covid there was a budget reduction, even this year and especially in this field is confusing so there are no temporary activities".

Lack of appreciation from the government for people with physical disabilities who excel. The statement was expressed by Dadang Efriandi, S.Pd as a coach for disabilities athletes stating that:

For me, many people don't even care about children with disabilities even though they have good achievements in the field of sports.

Analysis of the strategic situation resulted in four possible alternative strategies for developing sports tourism in the city of Bengkulu. The four possible alternative strategies are as follows:

The strategy of Strength Opportunity

1. Utilize tourist sites to hold sports sustainably for people with physical disabilities. (S1 O1)

2. Utilize the support of the tourism office to hold sports at the Semarak
Sawah Stadium and Youth Width Gymnasium in a sustainable manner for people with physical disabilities. (S2 O2)

3. Utilizing the support of the Head of Youth and Sports Office to develop the potential of athletes with physical disabilities by creating training programs and sustainable sports events in Bengkulu City. (S3 O3)

4. Utilizing NPC support to provide selfdevelopment training for trainers to be able to design sports tourism for physical disabilities in Bengkulu City (S4 O4)

5. Utilizing various social media applications to socialize and marketing sports tourism in Bengkulu City. (S5 05)

The strategy of Weakness Opportunity

1. Improving sports facilities and infrastructure for physical disabilities by involving three important elements, namely the government, the private sector, and the community. (W1 O1)

2. Utilizing the support of the tourism office to improve the quality of sports tourism management for physical disabilities. (W2 O2)

3. Maximizing the role of the Bengkulu City Head of Youth and affairs to develop a calendar of events Sports For people with disabilities on an ongoing basis. (W3 O3)

4. Maximizing the role of the NPC in implementing the empowerment of human resources to manage sports tourism. (W4 O4)

5. Maximize the use of social media applications to carry out socialization of sports tourism for physical disabilities in Bengkulu City. (W5 O5)

The strategy of Strength Threat

1. Develop a clear vision and mission to make Pantai Panjang Tourism Location a friendly sports tourism location for physical disabilities. (S1 
T1)

2. Equip facilities and infrastructure that are accessible for physical disabilities at the Semarak Stadium and Youth Sports Hall and increase promotion to the public about the achievements of athletes with physical disabilities. (S2 $\mathrm{T} 2$ )

3. Involving the Department of Youth and Sports, KONI, academics, private parties, and sports clubs in fostering sports achievements. (S3 T3)

4. Involving the private sector for the development of facilities and infrastructure for physical disabilities. (S1 T4)

5. Involving the private sector to develop sports clubs for people with physical disabilities. (S3 T5)

The strategy of Weakness Threat

1. Develop a clear vision and mission to improve the quality of sports facilities and infrastructure for physical disabilities. (W1 T1)

2. Improving the quality of sports tourism management for physical disabilities. (W2 T2)

3. Organizing sports events for people with physical disabilities on an ongoing basis in collaboration with the private sector. (W3 T3).

\section{CONCLUSION}

Sports tourism for physical disabilities in Bengkulu City has the power to be developed but also has a big threat. Therefore, it is recommended to use a diversification strategy.

\section{ACKNOWLEDGMENT}

The research team would like to thank Bengkulu University for funding this research through the UNIB 2021 Fundamental Research Scheme.

\section{REFERENCES}

Arawindha, U., \& Fitrianita, T. (2018). The Accessibility of People with Disabilities to the Tourism Activities in Batu City. Int'l J. Soc. Sci. Stud., 6, 47.

Chikuta, O., du Plessis, E., \& Saayman, M. (2019). Accessibility expectations of tourists with disabilities in national parks. Tourism Planning \& Development, 16(1), 75-92. https://doi.org/10.1080/21568316. 2018.1447509

Danso, A. K., Atuahene, B. T., \& Agyekum, K. (2017). Assessing the accessibility of built infrastructure facilities for persons with disabilities: A case of the Softline Interchange. International Conference On Infrastructure Development In Africa.

Darcy, S., \& Buhalis, D. (2010). Introduction: from disabled tourists to accessible tourism. In Accessible Tourism (pp. 1-20). Channel View Publications. https://doi.org/10.21832/9781845 411626-004

Hua, K. P., Ibrahim, I., \& Chiu, L. K. (2013). Sport tourism: Physicallydisabled sport tourists' orientation. Procedia-Social and Behavioral Sciences, 91, 257-269. https://doi.org/10.1016/j.sbspro.2 013.08.423

Kaganek, K., Ambroży, T., Mucha, D., Jurczak, A., Bornikowska, A., Ostrowski, A., ... \& Mucha, T. (2017). Barriers to Participation in Tourism in the Disabled. Polish Journal of Sport and Tourism, 24(2), 121-129. doi: 10.1515/pjst-2017-0013

Mapjabil, J., Marzuki, M., Kumalah, M. J., Tangavello, L., \& Abidin, M. K. Z. (2017). Sport as a tourism 
attraction in Malaysia: Potential and prospects. GeografiaMalaysian Journal of Society and Space, 11(12).

Mhanna, R. (2018). Sport tourism: new challenges in a globalized world. Journal of Sport Tourism. 24 (4), 349-351. https://doi.org/10.1080/14775085. 2018.1532948

Oetomo, M., Teddy, L., \& Adiyanto, J. (2020). Planning and Designing of International Football Stadium in Bengkulu Province (Doctoral dissertation, Sriwijaya University).

Osmanoglu, H., \& Üzüm, H. (2018). Evaluating the Service Quality of the Hotel Establishments in Sports Tourism about the Athletes. Higher Education Studies, 8(2), 29-36. doi:10.5539/hes.v8n2p29

Pratama, H. F., \& Sakti, B. (2016). Development Program In The Long Beach-Based To Tourists And Local Community Perspective. Ekombis Review: Jurnal Ilmiah Ekonomi dan Bisnis, 4(2). https://doi.org/10.37676/ekombis. v4i2.282

Rahadian, A., Ma'mun, A., Berliana, B., \& Nuryadi, N. (2021). Successful Elite Sport Policies: Indonesia at The 2018 Asian Games. Juara: Jurnal Olahraga, 6(2), 288-303. https://doi.org/10.33222/juara.v6i 2.1327

Sanusi, R. (2020). Analysis of Sports Tourism Based on Natural Resources in Karimun Regency. Jurnal Ilmu Keolahragaan, 3(1), 1-9. http://dx.doi.org/10.26418/jilo.v3i 1.34999

Siswanto, A. (2015). Eco-Tourism Development Strategy Balurannational Park in the
Regency of Situbondo, East Java, Indonesia. International Journal of Evaluation and Research in Education, 4(4), 185-195.

Sugiyono. (2017). Penelitian Kuantitatif, Kualitatif, dan R\&D. Bandung: Alfabeta.

Tan, W., \& Hasibuan, A. P. S. (2019). The Fulfillment of Cultural and Tourism Rights for Tourists with Physics Disabilities in Batam City. Journal of Judicial Review, 21(2), 145-167. 